\title{
The Dream of King Jehoash: A Textual Analysis
}

\author{
Keiko Mitani \\ The University of Tokyo \\ kmitani@mbr.suisui.ne.jp
}

\begin{abstract}
The term "apocryphal" has been applied to a broad range of medieval Slavonic texts. Many of them were composed in the Judeo-Hellenistic literary tradition and brought into the Slavic lands, forming a particular textual corpus abundant in a variety of contents and narrative styles. However, there is also a group of pieces regarded as Slavonic apocrypha but whose origin is unclear. The Dream of King Jehoash, a very short story written in Old Slavonic, is one of such texts, copies of which were mostly circulated from the $13^{\text {th }}$ to the 18th century in Russia. This paper compares nine copies of the Dream, including the oldest one, analyzes linguistic and structural features of them, and presents the early transmission pattern of copies. Based on a particular expression reminiscent of the one found in The Song of Songs, the author concludes that the Dream was a Slavonic creation.
\end{abstract}

\section{Keywords}

Slavonic apocrypha - The Song of Songs - Biblical translation in Slavonic - King Jehoash

The term "apocryphal" has been applied to a broad range of medieval Slavonic texts. Many of them were composed in the Judeo-Hellenistic literary tradition and brought into the Slavic lands, forming a particular textual corpus abundant in a variety of contents and narrative styles. However, there is also a group of pieces regarded as Slavonic "apocrypha" but whose origin is unclear. The Dream of King Jehoash [Сон царя Иоаса in Russian, Сънят на иар Йоас in Bulgarian] (further, the Dream), a very short story written in Old Slavonic, is typically seen as one such text, copies of which were mostly circulated from the 13 th to the 18 th century in Russia. 
It has been suggested that the Dream was partly, or wholly, translated into Slavonic from Greek, but no equivalent in Greek, or any other language, has been found. As is not unusual with texts without the Vorlage, no attempt has been mounted either to look for its protograph or to detect the transmission pattern of the copies. Precise characterization of the Dream as a literary piece has not been provided yet, although an established understanding is that it is an apocryphon. Thus, this text indeed needs deeper observation in order to be properly placed in the tradition of medieval Slavonic writings, and this will be the task of this paper.

The paper is structured as follows: firstly, the storyline, manuscripts, and previous study concerning this text are overviewed; secondly, linguistic features of Russian and Bulgarian manuscripts are described for the purpose of looking for the language of protograph; thirdly, the content and textural structure of the story are analyzed, and fourthly, the early transmission pattern of the text is reconstructed in reference to other texts appearing adjacent to the Dream. The analysis concludes that the text was composed by way of combiming the Slavonic tradition of apocryphal narrative and the style of exegetical writings popular in Byzantine-Orthodox literature.

\subsection{Story}

A rumor that King Jehoash had a dream reached Amaziah, King of Judah, who then sent Jehoash his message to offer a meeting. Jehoash responded by relaying his dream through his messengers.

The narrative of dream after this introductory statement starts with an unclear yet impressive phrase: грьзнъ ГАєєыи коупина иже на синаи сыи поустил в есть

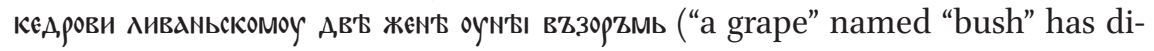
rected two pretty women to the Lebanon cedar standing on the Sinai mountain). This phrase, which might lead readers to anticipate the beginning of an unknown apocalyptic story, however, is followed by a narrative that runs not in a usual storytelling style but as a succession of fragmental phrases depicting different scenes without cohesive relationship between one another, for example: Two young pretty women, one of whom has a red face and the other - a white face; Abishag warms you; Big is the city, but small for me, and scarce are the people; a poor but wise man is in the city; it is him who saves the city besieged by a mighty king.

The narrative of the dream of Jehoash ends with the words addressed to Amaziah to explain all these. Amaziah, then taking the part of decipherer, 
gives interpretation to each phrase of the dream: купина in the first phrase of the dream, for example, means Jesus; кедр ливански represents a righteous belief for new people; of the two women-heralds, the one with a red face is the Old Testament while the other with a white face is a holy, true faith. After the interpretations of Amaziah, phrases referring to the verses of the Psalms appear and the story ends.

\subsection{Copies}

Copies of the Dream are dated from the 13th century, disseminated in Russia with one exception of Bulgarian provenance included in the "Ivan Alexander's Miscellany." The number of copies are estimated at several tens, but exact enumeration is supposedly difficult; not only because of the incomplete, fragmental copying of the text but also because of its interpolation into totally different texts. $^{1}$

The oldest extant copy, marked Q in this paper, is included in the collection Q.p.1.18, RNL (further, Qp18), fols. 1-3v, compiled in the first half of the 13th century in Russia. ${ }^{2}$ The next oldest copy $(\mathrm{O})$ is contained in the Codex F.205 (the OIDR collection), No.171, RSL (abbreviated as O171), dated the second half of the $13^{\text {th }}$ century. ${ }^{3}$ The other copies consulted, or referred to, in this paper are the following:

- T11 - RSL, the Library Collection of the Holy Trinity-St. Sergius Lavra, F. 304, I. No. 11 (abbreviated as TSL11), fols. 57-58v,14th c.

1 S. Ivanov, for example, noticed that the Dream was interpolated into one of Russian recensions of "the Story about the Twelve Fridays": С.В. Иванов, “«Сказание о 12 пятницах» и «Сон царя Иоаса»: взаимодействие двух апокрифических текстов," in: Индоевропейское языкознание и классическая филология - XV. Материалы чтений, посвященных памяти профессора Иосифа Моисеевича Тронского. 20-22 июня 2011 г. [S.V. Ivanov, "«The Story abot the Twelve Fridays» and «King Jehoash»: Interplay between two apocryphal texts," in Indoeuropean Linguistics and Classic Philology - XV. Materials of readings, dedicated to the memojry of professor Iosif Moiseevič Tronskij. Jun 20-22, 2011], Saint Petersburg, 2011, pp. 212-220; The Dream is also inserted into anthologies of texts ascribed to Ioannes Chrysostomos, ex.: «Bz срєAY

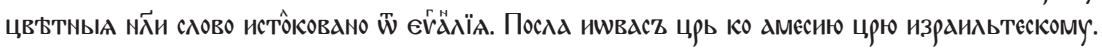
Толк. Амєсии цёZ рєчє, грєзмZ єсть $\vec{x}$ с.» (А.В. Горский, К.И. Невоструев, Описание рукописей московской синодальной библиотеки, Отдел II, Ч. 3 [Description of Manuscripts in the Moscow Sinodal Library, Devision II, Part 3], Moscow. 1857, p. 96.)

2 В.Н. Мочульский, “Сон царя Иоаса” [The Dream of King Jehoash], Русский филологический вестник, 37 (1897), pp. 97-113; H. Wątróbska, The izbornik of the XIIIth century: Cod. Leningrad, GPB, Q.p. I.18: Text in transcription (Полата кънигописьная, 19-20), Nijmengen, 1987.

3 А.А. Алексеев, “К истории русской переводческой школы ХІІ в.” [On the Russian Translational School of the 12th Century], тодРЛ, 41 (1988), pp. 154-196, here p. 155. 
- T122 - RSL, the Library Collection of the Holy Trinity-St. Sergius Lavra, F. 304, I. No. 122 (TSL122), fols. $15^{2 \mathrm{~V}-155}$, 15th c.

- T408 - RSL, the Library Collection of the Holy Trinity-St. Sergius Lavra, F.304, I. No. 408 (TSL408), fols.492-494V, 15th c.

- V- RSL, Volokolamskij collection, F. 113, No. 13 (V113), 16th c. ${ }^{4}$

- R - RGADA F.181 (RO MGAMID), op. 5. part. 2. 478/958 (RGD), fols. 533-533v, 16 th c. $^{5}$

- S - RSL, The Synodal Library collection, No. 235, fols. 102r-102v, 18th c.

A Bulgarian copy (IA) is included in Tsar Ivan Alexandăr's Miscellany of 1348 (BA), fols. 207-209v. ${ }^{6}$

\subsection{Previous Study}

P.A. Lavrovskij $(1858)^{7}$ was probably the first study to shed light on the Qp18, in which a copy of the Dream is contained. Although Lavrovskij mostly focused on the linguistic features of the collection, this surely generated scholarly interest in the Dream among researchers of subsequent generations, such as A.S. Uvarov (1896), ${ }^{8}$ V.N. Močul'skij (1897), ${ }^{9}$ V.M. Istrin $(1898),{ }^{10}$ and A.I. Sobolevskij (1911). ${ }^{11}$ Močul'skij's contribution of the publication of Q should remain highly estimated today, but his conjecture that the narrative of Jehoash's dream was composed by a Byzantine writer who was inspired by the Church art, whereas the interpretation part was later supplemented by a Slav, was severely criticized by Istrin as baseless. The latter remarked that the source text, which

4 Алексеев, “К истории русской переводческой школы," р. 157.

5 Д.В. Каштанов, “Русь и Фессалоника в XII-XIII веках: люди, идеи, пути” [Rus' and Thessalonica in the 12-13th Centuries: People, thoughts and roads], Византийский временник, 65. (2006), pp. 94-106, here p. 96.

6 E. Zashev, Lavrentiy's Miscellany. Tsar Ivan Alexandăr's Miscellany of 1348. Phototype edition, Sofia, 2015; see also: К. Куев, Иван Александровият сборниик от 1348 г. [Ivan Alexander's Miscellany in 1348], Sofia, 1981.

7 П.А. Лавровский, “Описание семи рукописей императорской публичной библиотеки" [Description of the Seven Manuscripts in the Imperial Public Library], Чтения оидр (1858), No. 4, pp. 3-9o; particularly pp. 17-24.

A.С. Уваров, "Рисунок символической школы XVII въка" [A Drawing of the 17th-century Symbolic School, Археологические известия и заметки (1896), No. 4, pp. 93-99. See note 2.

10 В.М. Истрин, “К вопросу о 'сне царя Иоаса': По поводу статьи проф. Мочульского” [On the Question about 'the Dream of King Jehoash': In regard to the prof. Močul'skij's article], Журнал Министерства народного просвещения (1898, February), pp. 300-308. А.И. Соболевский, “Неизвестный русский паломник” [An Unknown Russian Pilgrim], ИОРЯС, 16, 1 (1911), pp. 5-7. 
should have been written in Greek, was not composed at one stroke but was gradually compiled over years by many writers. According to Istrin, this can explain the disorganized yet still unique textual structure of the Dream.

In recent years, M. Babitskaja (1995) ${ }^{12}$ examined the composition of Qp18 and concluded that this collection, as well as other collections of similar contents compiled in Russia, has an antecedent of East Slavonic provenance; however, no mention was made in reference to the Dream. In a series of works concerning the Slavonic translation of the biblical book of the Song of Songs, A.A. Alekseev more than once touched upon the Dream (Alekseev 1983, 1985, 1988, 2002) and suggested that the Slavonic version might have first been translated in the South Slavic region from a Greek text whereas the interpretation part could have been a creation in Kievan Rus. ${ }^{13}$ D.V. Kashtanov noticed this story in his study of fragmental texts extracted from the exegesis of Psalms appearing after the Dream in several copies, and guessed in relation to those fragmental texts that the Dream already existed by the end of the 12 th century. ${ }^{14}$

As for the South Slavonic copy, IA, K. Kuev (1981) gave a brief description of the Dream in his commentary to BA, ${ }^{15}$ whereas, in I. Zašev (2015) ${ }^{16}$ no particular mention was provided in regard to the Dream.

2

\section{Languages}

\subsection{Russian Copy Q}

This section will sketch linguistic features of $\mathrm{Q}$, the oldest Russian copy, and the sole Bulgarian copy IA. The purpose of doing so is to search for clues to the language of protograph, since the possibility of the South Slavic origin of the Dream has been repeatedly suggested, while the copies were mostly circulated in Russia, including the oldest one dating from the 13th century.

12

М. Бабицкая, “Источники Изборника ХІІІ века [Origins of a 13th-century Miscellany] (Cod. St. Petersburg, GPв Q.p.1.18)," Byzantinoslavica, 56 (1995), pp. 631-635.

13

Алексеев, “К истории русской переводческой школы," р.181; А.А. Алексеев, “Цитаты из Песни песней в славянской письменности” [Citations from Song of Songs in the Slavonic literature],Старобългарска литература, 18 (1985), pp. 74-92; idem, “Копределению объема литературного наследия Мефодия (Четий перевод Песни песней)" [On the Definition of Range of Methodius's Literary Legacy ('Četij' translation of Song of Songs)], ТОДРЛ, 37 (1983), pp. 229-255; idem, Песнь песней в древней славяно-русской письменности [Song of Songs in Old Slavonic and Russian Literature], Saint Petersburg, 2002.

Каштанов, “Русь и Фессалоника,” р. 101.

Куев, Иван Александровият сборник, pp. 383-385, 389-39о.

Zashev, Lavrentiy's Miscellany, pp. 11-64. 
The reason for our selecting $\mathrm{Q}$ as an object of examination among Russian copies is not only because $Q$ is the oldest extant text but also because it looks most reliable in reference to textual quality. Let us compare, for example, $\mathrm{O}$ (the second oldest copy) with Q. O lacks the first part of the story, and the following is the beginning of the extant part:

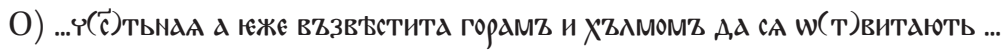

... it (the belief) is honorable (?), and the two announce to mountains and hills that they themselves "otvitajut"17

This is most likely a part of Amaziah's interpretation of the dream, and the corresponding phrase in $\mathrm{Q}$ reads:

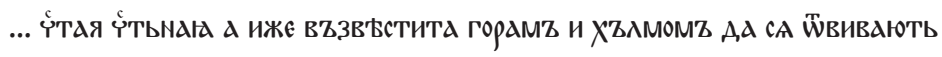

... it (the belief) is pure and honorable, and they two announce to mountains and hills that they themselves "otvivajut"'

The obvious closeness of these two indicates that they are copied from a common source; however, the form of the relative pronoun in $\mathrm{O}$, єжє, obviously disagrees with the verb form възвьстита, which is in the 3 rd person dual present form. Moreover, the verb w(т)витают сл ('dwell themselves'?) in O looks to be an error in comparison with Q's штвивають сA ('disclose themselves') and the similar forms appearing in the corresponding position of other texts (T11: шьивають, Т408: овивают, Т122: ӝвиваютТ).

Defects and errors are found in different degrees in other younger manuscripts, too. T11, which is as complete a text as Q, for example, also shows errors in copying, as illustrated below:

(Q) ОБАВИ ЖЕ СА О ТОМЬ АМЕСИИ ЦРЮ НЮОАИНОУ И ПОСАА АМЕСННА

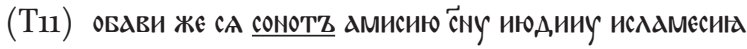

Here, o томь in Q is changed in T11 to сонот, which is evidently an error, and ameсии црг июдиноу in $\mathrm{Q}$ is miscopied to дмисию снуу июдиичу (to Amaziah, Son of Judah").

17 Сводный катаолог славяно-русских рукописных книг, хранящихся в сссР. ХІ-ХІІІ вв.[Repertory Catalogue of Slavonic-Russian Old Manuscripts from the 11th-13th centuries, kept in UssR], Moscow, 1984, p. 312. 
These defects and errors in other copies give us good grounds to estimate $\mathrm{Q}$ as a copy that is closer than others to the Russian protograph and to take it as an objective of observation. Further, this manuscript will be used for the citation, too.

The language features that Lavrovskij remarked on in his observation of Qp1818 naturally hold true to $\mathrm{Q}$. The jers in strong positions are retained in certain degree, whereas weak jers are mostly omitted: c'snz ('dream,' nom.sg.), but сна (gen.sg.); мне (dat.1sg, against the proper OR form мZNе); слы (< сълъ 'herald,' acc.pl.). Thus, the way in which jers are used in Q matches the general tendency of treatment of jers in the writing tradition of Kievan Rus. ${ }^{19}$ Pleophonic forms are found as in под, голову, ${ }^{20}$ истекаюощеє молоко, ${ }^{21}$ and връви висоц' акы чьрнилzмь 3 зволочен' ${ }_{2}^{22}$ but their occurrence is not consistent; rather, it is accompanied with the South Slavonic alternatives: гАдвоу оувазеноу, оувазеная гесть гААва. As for граАZ, the pleophonic form городZ is not attested. Inter-consonantal diphthongs, originating from the Proto-Slavic ${ }^{*} \mathrm{~T}_{\mathrm{b} R T}$ and ${ }^{*} \mathrm{~T}_{\mathrm{b} R T}$, are

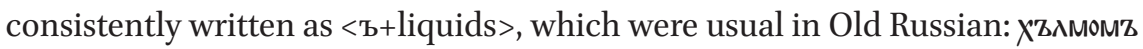
(<"hъlmъ, осs:хлZмь); ${ }^{23}$ пьрвоке (<"рьrvъ, осs:прьвъ). ${ }^{24}$ The big jus is not used, the etymological * $Q$ being represented by oy or ю: pоукоу (<ркка, асc.sg.); ст'вкаюџєек $(<[и]$ стеции, active participle present, n.nom.sg). The small jus is often replaced with is or $\mathbf{\Delta}$ : рєша (<рєци, aor.3.pl.). It can be noted also that the preposition repetition, a feature typically observed in medieval Russian writings, is attested: $\mathrm{kz} \mathrm{Hoдсоу} \mathrm{къ} \mathrm{сноу} \mathrm{ахазовоу.} 25$

Along with these Russian features, Q shows archaic features as well, such as

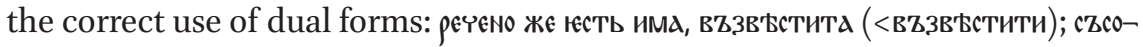
ма над,онть (<Съсъ, instr.du.), and the dative absolute structure: ист'вкаююџю молокоу по изовилоу. ${ }^{26}$

On the basis of these observations, we can state that Q was definitely written in Russia, but several features, such as the use of South Slavonic forms

18 Лавровский, “Описание семи рукописей,” р. 18.

19 В.И. Борковский, П.С. Кузнецов, Историческая грамматика русского языка [Historical Grammar of Russian Language], Moscow, 2006, pp. 99-100.

20 Т11, Т408: Под, ГААву.

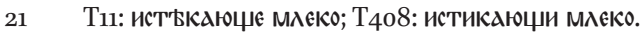

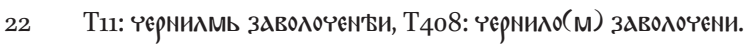

23 T122, Т408: ХОлмом'Z, IA: ХАЬмWM'Z.

24 T11, Т408: Первоя, IA: прZB'Ъ̈.

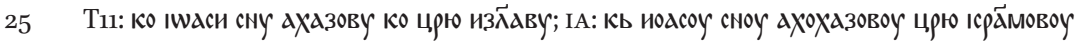

26 For the use of dative absolutive in oR, see Борковский, Кузнецов, Историческая грамматика русского языка, pp. 445-446. 
without pleophony, along with the grammatical archaism, may hint at the South Slavic origin from which the Russian copy was composed.

\section{$2.2 \quad I A$}

Let us turn our attention to IA.

Here, medieval Bulgarian innovative features are conspicuous, such as the use of juses in etymologically unrelated positions: ${ }^{27} \mathrm{~A}$ for the etymological *Q

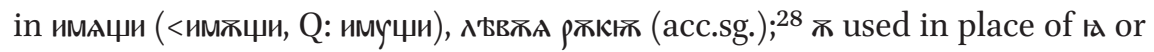
А: жзыкъ (<*е̨zykъ, meaning 'people'); 29 умножишж сA (aor.3.pl. < умможити сA). ${ }^{30}$ At the same time, old features are retained, for instance, сыи (<сжтъ [быти]), in spite of the medieval Bulgarian tendency from the 12th century to replace $b$ with $x$ in the ending of the masculine nominative singular of the active participle present. ${ }^{31}$

Amongst other features outside phonological ones we may notice:

- the dative absolute phrase, which correctly occurs in Q, is changed into стАчажцк мл'кко. This could be read as a scribe's reinterpretation of the dative absolute in the source text into the usual participial phrase with the nominative singular feminine form of the active participle of the verb стачати ('shed') followed by мх'кко as the direct object, ${ }^{32}$ meaning 'shedding milk'; otherwise it could be a simple error in copying.

- $\quad$ one of the two women appearing in Jehoash's dream is depicted in Russian copies as "has a red face with black eyes" (Q: жчии смагл'), but, in IA, the adjective cm'brлa modifies the second woman who should be "white," resulting in a formation of the contaminated phrase другда же см'Бгла Б'Ао лице: "another black(?) woman (has) a white face."

Another deviance which looks to be a result of a scribe's miscopy is АминодАва

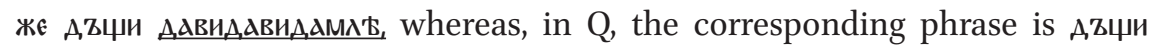
ААвидАмлА: “David's(?) daughter."

27 К. Мирчев, Историческа граматика на Бьлгарски език [Historical Grammar of Bulgarian Language], Sofia, 1963, pp. 102, 104-105.

28 Q: $\lambda$ 'bsyoro poyky.

29 Т11: языкъ.

30 Т11: оумножишасА.

31 Мирчев, Историческа граматика, р. 214.?

32 The use of the verb истачати as a transitive can be found in: єсти а вZ земА Благж. истАч'ВАџХА Мл'Бко и медZ: J. Kurz, et al. Slovník jazyka staroslověnského (Словарь старославянского языка. Репринтное издание) [Dictionary of Old Church Slavonic (Reprinted edition)], Saint Petersburg, 2006, vol. 1, p. 814. 
Difference in lexical selection is scarcely observed between IA and Q, with one clear divergence: прњдьстити in IA and съьлдзнити in Q:

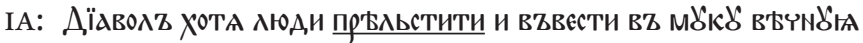

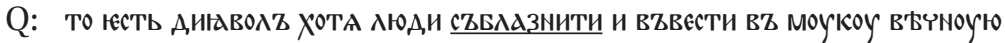

This difference, however, does not provide us with any key to define the place or time of origin of these copies, as both verbs were used in Old Slavonic; i.e., in medieval Bulgarian as well as Russian writings.

Thus, our sketch of the linguistic features of $Q$ as well as IA revealed that both $\mathrm{Q}$ and IA show orthographic features of medieval Russian and Bulgarian writings, respectively. To define the language of protograph of the Dream from comparison of these two copies is therefore hardly a promising endeavor. Nevertheless, some lexical features may indicate the South Slavic origin of the Dream, such as десница 'a right hand' and the use of книга to mean 'a book (of the Bible)': оучение стых книгz. ${ }^{33}$ It has been suggested in previous studies, as in Alekseev (1985), that the part of Jehoash's dream may have first appeared in the South Slavic region, but the interpretation part could be a later addition in Kievan Rus. However, the linguistic features of Q look to contradict such a hypothesis, as pleophonic forms (ГОловд, зАволочен') mostly appear in the dream part, while, in the interpretation part, the South Slavonic forms without pleophony are dominant. If the dream part were of South Slavic composition and the interpretation were a Russian addition, the appearance of pleophonic forms would be opposite. The possibility, as has been suggested by Močul'skij (1868) and Istrin (1898), that the Dream was composed gradually, firstly the dream part and later the interpretation part, cannot be denied; however, it is hardly conceivable that the first appearance of the Dream was in Kievan Rus and that the text was then introduced to the South Slavic region where the interpretation part was added before being brought back into Russia. The simplest way to understand the formation process of the Dream would be that the text as a whole was first composed in a South Slavic region, most likely Bulgaria, and then brought into Russia, where it underwent rewriting in compliance with scribes' habits of Kievan Rus. The reason why the pleophonic forms are more favored in the dream part than in the interpretation part should be examined separately, which is outside the scope of this paper. 


\section{3}

\section{Composition and Content of the Text}

The Dream is composed of the introductory segment, the main narrative as a core part, and a short coda. The main narrative is two-partite: the narrative of Jehoash's dream, and interpretations given by Amaziah.

It has been already noted in the previous study that the Dream was a compilation of biblical books and drew particularly on The Song of Songs, The Kings, and the book of Ecclesiastes. Indeed, as we will see below, the author(s) of this short piece must have made the best use of these books; however, the strategy that the author(s) selected for referring to them is not simplex but ranges from plain quotation, though partial modification, to free adaptation. In addition, not only the biblical books but also the exegeses of the biblical books were used for composing this piece.

\subsection{Introductory Segment}

After the opening clauses of "in the time of the Prophet Isaiah, Jehoash, King of Israel, dreamed, and the rumor somehow reached King Amaziah of Judah," the phrases telling of the reaction of Amaziah follow. Having heard about the vision that Jehoash experienced, Amaziah sent heralds to Jehoash:

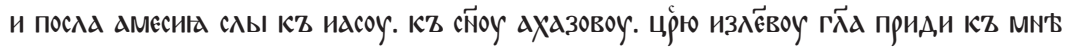

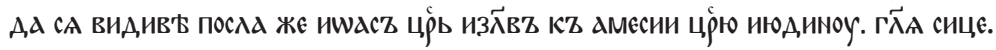

This is obviously a direct quotation from the Bible; compare this part with 2 Kings 14:8-9:

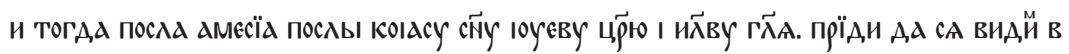
лице. И послА иод ц

Then Amaziah sent messengers to Jehoash, the son of Jehoahaz son of Jehu, king of Israel, saying, "Come, let us look one another in the face." And Jehoash the king of Israel sent to Amaziah king of Judah, saying, ... ${ }^{35}$

Once readers understand that it is a quotation from 2 Kings, the relationship between this introductory part and the successive, seemingly unclear, sentenc-

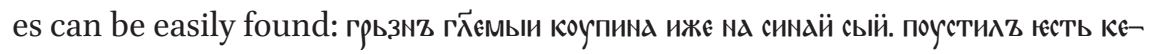
Арови ливаньскомоу ав' жен' оун': ..., as the corresponding part of 2 Kings

34 The Ostrog Bilble.

35 Quoted from the King James Version. 


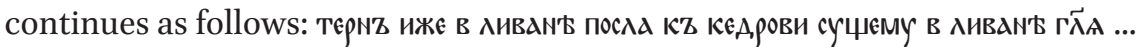
("The thistle that was in Lebanon sent to the cedar that was in Lebanon, saying ...")

What is peculiar in this introductory segment is that, in contrast to the usual way of beginning a story, according to which a narrator provides readers with initial background information on the development of the narrative or the theme of story, the opening phrases of this story function only to introduce the names of two biblical persons: Jehoash and Amaziah. Neither of these two persons plays a crucial role in the development of story, nor does the relationship of the two kings narrated in the Book of Kings have any relevance to the content of the Dream. Still, this peculiarity can be explained if we estimate that introducing the biblical persons at the onset of the story had significance in relating this story to от and placing it in the tradition of medieval OrthodoxChristian writings formulated around the biblical, as well as other books related to them.

\subsection{The Main Narrative}

The dream part is made up of phrases associated with the biblical texts in various ways. While the beginning phrase of the dream “грьзнъ гієємыи коупина ижє на синаии сын. Поустил乙 кеть кеА,рови ливаньскомоу" is a direct quotation of 2 Kings 14:9, “тернъ иже в ливан' посла кZ кедрови сущєму в ливан'," the successive sentences depicting two women can be characterized as a free adaptation of the Song of Songs. A phrase starting with "юдина роумано хице имучи," for example, is probably associated with the phrase in Song 1:4-5: "Үрzна юесмz и д, ОБра ... АзZ

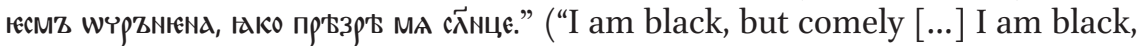
because the sun hath looked upon me."). Relatedness to Song is more clealy

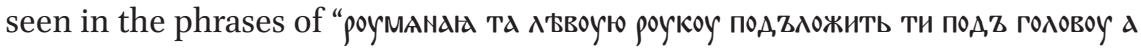

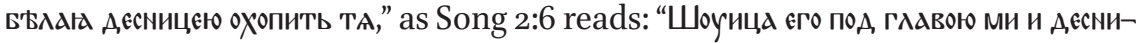
цА єго овынметъ ма." 36 ("His left hand is under my head, and his right hand doth embrace me.")

A curious phrase is Ависага жє да сZГр'Беть тА: the appearance of the name Ависага, which should mean Abishag, a young woman narrated in the Book of Kings, ${ }^{37}$ looks sudden here, as the narrative obviously drew on the Song. However, "Shunamite," the epithet for Abishag, has been identified in various cultural traditions with "Shulamite," mentioned in Song 6:13[7:1]. ${ }^{38}$ Indeed, in the

\footnotetext{
$36 \quad$ The Ostrog Bilble.

$37 \quad 1$ Kings 1:1-3.

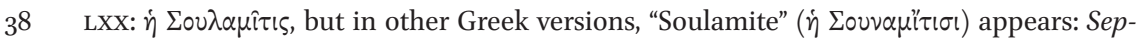
tuaginta, id est, Vetus Testamentum graece iuxta LXX interpretes, ed. A. Rahlfs, Stuttgart,
} 
oldest Slavonic translation of the Song, RNL F.I. 461, the said part reads as "Соулдмитьвини,"39 but the identification of "Shulamite" and "Shunamite" was surely known in the early literature of Slavia Orthodoxa, the proof of which is found, for example, in the Slavonic translation of Pandects, dated from the 12-

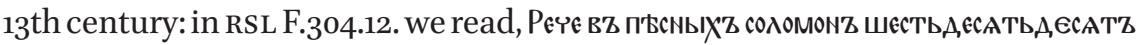

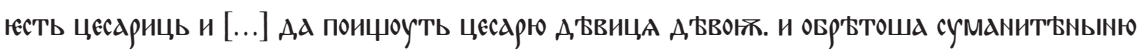

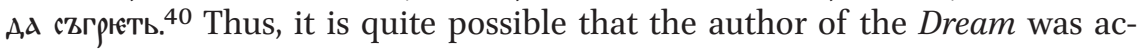
quainted with such identification of "Shulamite" and "Shunamite," and this association was reflected to the occurrence of the name Ависага in the narrative of this work.

We should note another interesting phrase: "АминодААВА Же АВџи д,АвидадмлА. имоуши ноз' въ сапоз'Х." The literary interpretation of "АминодАВА жє АВџи дАвидАмлА” " would be 'Aminodava, the daughter of Davidam(?),' but the name Aminodava is not known in biblical books. Although a nearly identical expression in the от, "the daughter of Aminadab," might connect the said phrase to Esther, ${ }^{41}$ we prefer to offer a different interpretation in reference to another expression akin to the phrase in question, found in the old Slavonic translation

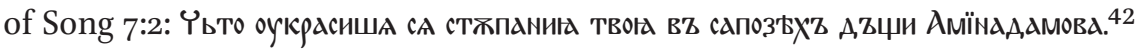
The closeness of the expressions of аминодава жє двщи and дъчии Амїнадамова suggests that the latter was utilized as a model for the former.

After the sentences depicting the two women, we encounter again a plain

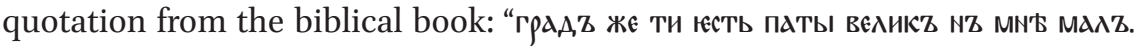

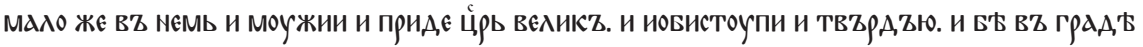
томь моужь ниць нъ моуард и тъ моужь спісе(ть) граАZ." Compare this part with

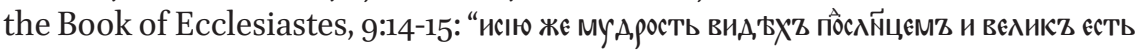

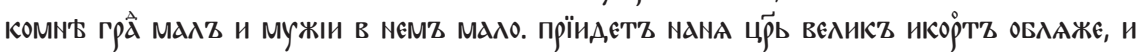

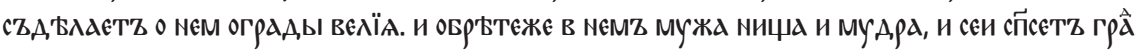
мудростін своєю." "There was a little city, and few men within it; and there came

1935, p. 266; G. Barniero, Song of Songs. A Close Reading, Leiden - Boston, 2011, p. 364; Also in Syrian and Arabic traditions "Abishag the Shunammite" is understood as the same woman as "Shulamite," which results in "Abishag the Shulamite": I. Kalimi, "The Rise of Solomon in the Ancient Israelite Historiography," in: The figure of Solomon in Jewish, Christian and Islamic Tradition: King, sage and architect, ed. J. Verheyden, Leiden, 2013, p. 10. Алексеев, “К определению объема литературного наследия Мефодия,” р. 253

40 See The Pandects of Antiocus. Slavic Text in Transcription. Полата кънигописьная, ed. J. Popvski, Amsterdam, 1989, p. 4.

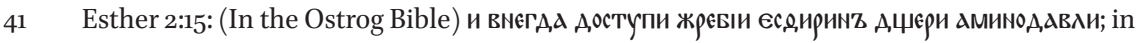

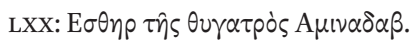


a great king against it, and besieged it, and built great bulwarks against it. Now there was in it a poor wise man, and he by his wisdom delivered the city.")

After the abovementioned quotation from Ecclesiastes, the dream part ends and the interpretation of the dream starts. In this part, the phrases in the previous part are repeated, and each is provided with an interpretation; for exam-

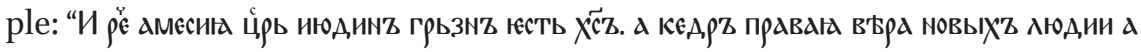

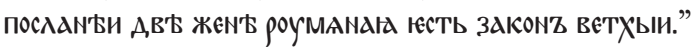

It is obvious that the author employed the writing style of exegetical texts; particularly the biblical exegeses. Let us take for the sake of illustration a passage from a Slavonic translation of the exegesis on Song, originally composed by Philo of Carpasia (†410): “Шюица єГо Под Z ГААвою ми и Аєсница єГо

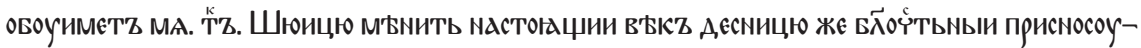
чи животь ... ".43 A word “толкz," shown in this example, or the letter т, were often used by scribes of this genre of text to mark the phrases of interpretation, and, indeed, the scribe of Q employed this convention as well; ex.: “... главоу

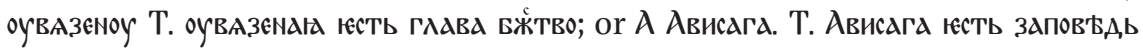
c'TAra..."

Not only the style but also the content of the biblical exegeses was adopted. The phrase in the dream, "There was a little city, and few men within it... ," which is in fact a quotation from the Ecclesiastes, is interpreted as "the city is a church, a poor wise man is Christ." This was in fact a quotation from the Byzantine exegetical writing on Ecclesiastes. ${ }^{44}$

After the interpretation there appear the last phrases: "пррјкъ во рєчє. правь-

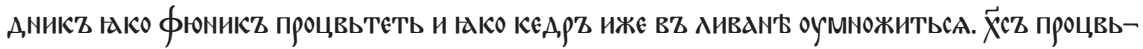
те нако фноникZ стии оумножишаса ғако кедри во̆ же наше." This passsage, which does not correspond to the content of Jehoash's dream and thus looks to be added as a coda, is again a modification of the Bible; this time Psalms 91:13:

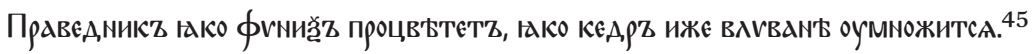

\subsection{Summary of This Section}

Our observation in this section enables us to state the following.

The first part of the Dream can be characterized indeed as apocryphal because of the appearance of biblical persons with starting phrases of ambiguous yet apocalyptic implication, although the two biblical figures, Jehoash of Israel and Amaziah of Judah, do not play any role in the story other than as 'a

43 Алексеев, Песнь Песней, р. 76.

44 Алексеев, “К истории русской переводческой школы,” р. 186.

45 The Ostroh Bible. 
dreamer' and an interpreter, and there are no apocryphal stories related to these two Kings.

Moreover, the textual structure made up of the dream accompanied by its interpretation is in accordance with other apocryphal stories disseminated in medieval Slavonic literature, such as the South Slavonic version of the Story about Sibyl and the Story of the Twelve Dreams of Shaxinsha. These features have probably led researchers of the previous study to place this text in the Slavonic apocryphal tradition. At the same time, the utilization of the style and contents of biblical exegeses makes this text appear closer to exegetical texts.

In sum, the Dream can be characterized as a unique composition created through the conjunction of apocryphal settings and the style of exegetical writings.

\section{$4 \quad$ Textual Environment}

Investigating the environment in which particular text occurs is important not only for characterizing the function of that text in broader intertextual relationships with other texts, but also for tracing its transmission pattern. This section focuses on this question.

The following table shows the textual environments of the Dream; i.e., texts appearing adjacent to the Dream in the miscellany and collections that fall under the scope of our examination.

\begin{tabular}{|c|c|c|c|c|c|}
\hline BA & Qp18 & $\begin{array}{l}\text { TSL11 } \\
\text { "Golden Chain" }\end{array}$ & $\begin{array}{l}\text { TSL408 } \\
\text { "Stihirar" }\end{array}$ & TSL122 & $\mathrm{O}_{171}$ \\
\hline $\begin{array}{l}\text { Questions and } \\
\text { responses } \\
\text { Что ради попуси } \\
\text { Б̈ }\end{array}$ & & $\begin{array}{l}\text { On the Holy } \\
\text { Friday and the } \\
\text { Passion of Jesus }\end{array}$ & $\begin{array}{l}\text { Wisdom of Sirah } \\
\text { (Questions and } \\
\text { responses) }\end{array}$ & $\begin{array}{l}\text { Words from } \\
\text { various books } \\
\text { (containing } \\
\text { 'Solomon's } \\
\text { chalice') }\end{array}$ & $\begin{array}{l}\text { On the Gospel } \\
\text { and the } \\
\text { Resurrection } \\
\text { (fragments) }\end{array}$ \\
\hline the Dream & the Dream & the Dream & the Dream & the Dream & the Dream \\
\hline 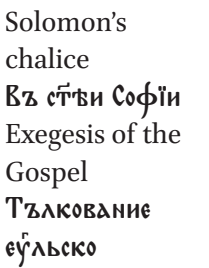 & $\begin{array}{l}\text { Solomon's } \\
\text { chalice } \\
\text { Вz сти Софьи } \\
\text { From the Gosple } \\
\text { отZ євАнГілина }\end{array}$ & 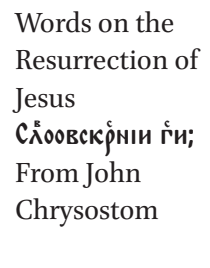 & $\begin{array}{l}\text { Solomon's } \\
\text { Chalice } \\
\text { Вz ст Софьи } \\
\text { єсть к'Аина; }\end{array}$ & $\begin{array}{l}\text { Words of } \\
\text { Gregory the } \\
\text { Theologian, }\end{array}$ & $\begin{array}{l}\text { Remarks on the } \\
\text { Psalms } 28.5 \text {, } \\
36.35,71.16\end{array}$ \\
\hline
\end{tabular}


This table clearly shows that the Dream was circulated together with, or attached to, the biblical exegeses and other didactic, and explanatory, texts. In this environment of occurrence, we notice two patterns of adjacency that look to be important for detecting the transmission pattern of the Dream. One of them concerns the occurrence of textual unit consisting of exegetical remarks on three verses of the Psalters, and the other is the appearance of a short story broadly known as "the Story of Solomon's Chalice."

The first pattern was noticed by Kashtanov (2006), according to which short explanatory remarks on three verses of Psalms 28:5, 36:35, and 71:16 ("the three remarks on Lebanon") appear immediately after O, V, and R, in O171, V113, and RGD, respectively. ${ }^{46}$ The occurrence of the same textual unit in the adjacent position would strongly suggest that $\mathrm{O}, \mathrm{V}$, and $\mathrm{R}$ were on one and the same line of textual transmission.

In this relation, we notice that Qp18 contains an exegesis of Psalters, and the phrases referring to the verses 28:5 and 36:35 in it are almost identical with those found in O171. Compare 28:5. in these two collections: ${ }^{47}$

\begin{tabular}{|c|c|c|}
\hline & Qp18 & $\mathrm{O}_{171}$ \\
\hline 28:5 & 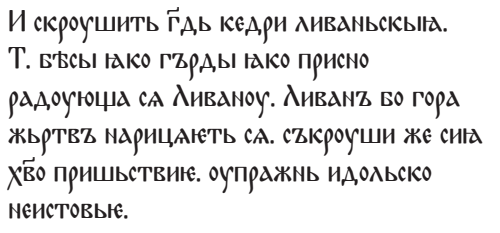 & 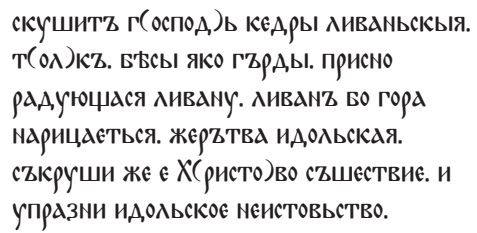 \\
\hline
\end{tabular}

This correspondence might seem to indicate that "the three remarks on Lebanon" in $\mathrm{O}$ were formed as an extraction from the exegesis of Psaltir included in Qp18. At the same time, however, divergence between these two collections is found in the explanation of 71:16:48

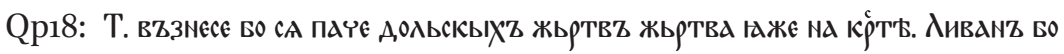
СКАЗАКТЬ СА ЖИХИЧЕ ИА,ОЛЬСКО.

46 Каштанов, “Русь и Фессалоника," p. 96.

47 Qp18: Wątróbska, The izbornik, p. 72; О171: Каштанов, “Русь и Фессалоника," p. 96.

48 Qp18: Wątróbska, The izbornik, p. 96; О171: Каштанов, “Русь и Фессалоника,” p. 96. 


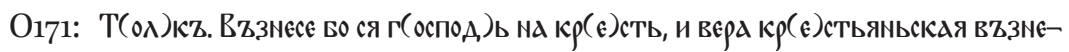

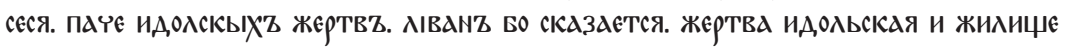
Б'BCOBbCKOC.

As the text in $\mathrm{O}_{171}$ is not a reduced but an extended version compared to the one in Qp18, we may opt to consider the possibility that "the remarks" on Lebanon in O171 were not directly formed from the exegesis of Psalter contained in Qp18 but were transmitted from another, intermediate, source between these two collections. Still, the close connection between Op18 and $\mathrm{O}_{171}$ is indisputable.

Another notable pattern in reference to the textual environment of the Dream is the neighboring appearance of "the Story of Solomon's Chalice." The adjacency of "Solomon's Chalice" to the Dream is found in BA, Qp18, and TSL408. In TSL11 the Chalice story appears, too; not after but before the Dream, being inserted among various short pieces. ${ }^{49}$ In RGD, which, like O171, contains the remarks on "Lebanon" after the Dream, the last sentence of "Solomon's Chalice" appears after the remarks on Lebanon: "and found (that) from the twelfth year of Solomon's reign to the reign of Christ there (are) nine hundred and nine years." 50

"The Story of Solomon's Chalice" is a short text, well known in Slavic philology due to its inclusion as the chapter XIII of Vita Constantini (VC). ${ }^{51}$ Regarding the story appearing as chapter XIII of VC, much discussion has been done, mainly about whether the Chalice episode was an original part of the vC or a later interpolation. ${ }^{52}$

The Chalice story had been considered a Slavonic creation, probably written by Constantine-Cyril himself, until the discovery by Shevchenko (1967) of a Greek fragment that corresponds to the Slavonic version of the Chalice. After

49 “Словеса избранна от многих книг различных строк”[Words, selected from various books of different writers].

50 Каштанов, “Русь и Фессалоника.”

$5^{1}$ Vita Constantini-Cyrilli (Житие Константина).

$5^{2}$ I. Ševčenko, "The Greek Source of the Inscription on Solomon's Chalice in the Vita Constantini," in: To Honor Roman Jakobson: Essays on the Occasion of his Seventieth Birthday 11 October 1966, vol. III, The Hague, 1967, pp. 1806-1817; R. Picchio, "Chapter 13 of Vita Constantini: Its Text and Contextual Function," Slavica Hierosolymitana, 7 (1985), pp. 133-152; M. Taube, "Solomon's Chalice, the Latin Scriptures and the Bogomils," Slovo, 37 (1987), pp. 161-169; M. Capaldo, "Respect of the Textus Traditus or Venture into Conjecture? On a recent interpretaion of the Vita Constantini 13," Палата кьнигописьная, 25-26 (1994), pp. 4-92; P. Balcárek, "Some Remarks on Solomon's Chalice in Vita Constanini," Palaeobulgarica, 35.1 (2011), pp. 34-51. 
this discovery, it became an established understanding that the Slavonic version is a modification of the Greek antecedent. Outside vC, two recensions of the Chalice story are known. One is shorter, containing an interpretation added after the basic text of the Chalice, and the other is longer, showing a further textual transformation such that each verse of the basic text is accompanied by an interpretation and embedded into an exegetic writing of anti-judaistic vein, traditionally referred to as the "Words of the Holy Prophets". ${ }^{53}$ The copies transmitted with the Dream belong to the shorter version (abbreviated here as SolChalT).

As Picchio (1985) notes, SolChalT was transmitted, occurring in various miscellanies of exegetic character, with the total number of copies amounting to around $30 .{ }^{54}$ It is notable that the four earliest copies of SolChalT, composed from the $13^{\text {th }}$ to $15^{\text {th }}$ centuries, were included in Qp18, BA, TSL408, and TSL122, emerging in a position neighboring, or close to, the Dream. Of them, those included in Qp18, BA, and TSL408, namely, the copies placed immediately after the Dream, are most likely derived from the same antigraph; this can be confirmed by comparing the starting part of these copies of SolChalT:

BA

Qp18

TSL408

ВZ стТБи софїн есть келїА CONOMWN'B. $\widetilde{W}$ KAMENE

А.рАГАГо А,'СААна. нАNен Же NАПисАNИ сжТЬ стиси Трне. еВренскЫ И САМАренскЫ ПисменЫ.
ВZ стТ' софZи юеть келыға CONOMONA. OTZ KAMENDIA А,РАГОГА А'СААNА. на NенЖе соу'ТЬ NАПИСАNИ стиси Трью. кеврьискы и самар' Бискы ПисменЫ.
Вz ст Софьи есть к'ЪАна Conomona w kamenila А.РАГАГО А,'ААНА. нА NеН Же су написаны стиси трие.

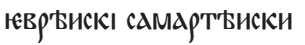
ПисмеNЫ.

The closeness of these three $\backslash$ copies is well illustrated by the word кєлия, which commonly appears in them, in contrast to $\mathrm{VC}$, where the word found in the equivalent place is потирь. ${ }^{55}$ On the basis of this evidence of adjacency, we can state that Q, IA, and T408 formed one line of transmission.

Thus, from what has been observed, it is possible to restructure an early transmission pattern of the Dream, as below:

53 Capaldo, "Respect of the Textus Traditus," pp. 9-10.

54 Picchio, "Chapter 13 of Vita Constantini," p. 140.

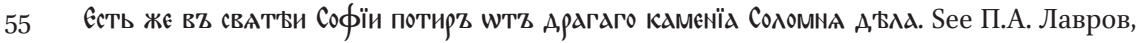
Материалы по истории возникновения древнейшей славянской письменности [Materials on the Yistory of Emergerce of the oldest Slavonic Literature], Leningrad, 1930. 


\section{《 Early transmission pattern of the Dream 》}

C+ : SolChalT is in adjacent, or very close position

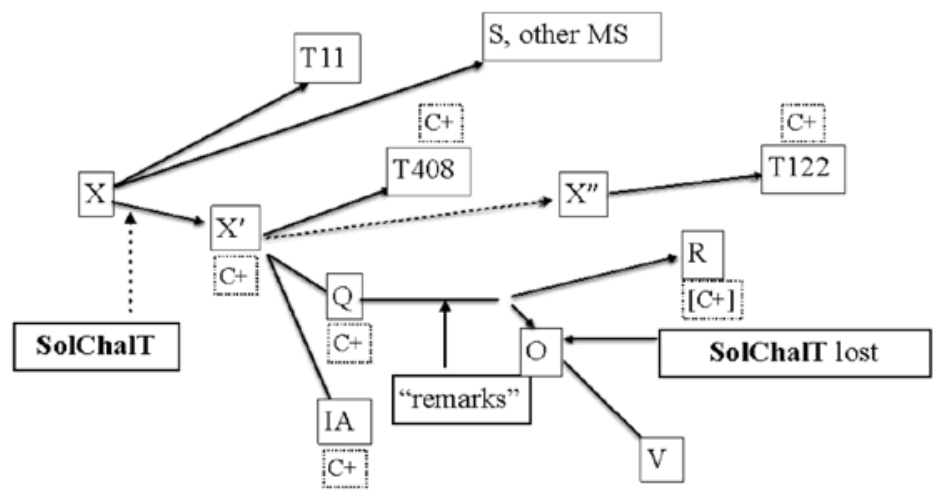

Suppose that $\mathrm{X}$ is the protograph of the Slavonic version of the Dream; it should have been included in a collection in which SolChalT was also included, and there a transmission pattern of the Dream followed by SolChalT was formed. The formation of this pattern is not surprising, given a perceptible parallelism between the Dream and SolChalT: both contain apocryphal elements; the story is made up with a message that should be deciphered (a dream, and the verses never read) and its interpretation. This transmission pattern, most likely formed by the end of the 12th century, was further succeeded by Qp18, BL, TSL408. The adjacency of T122 and SolChalT in TSL122 also allows us to place T122 on the same transmission line as Q, IA, and T408. However, TSL122 differs from these three not only in the order of the Dream and SolChalT but also by the textual deviation of SolChalT, as the SolChalT in TSL122 starts: св. Софии єсть комора Соломана сына Аавида от камени аругаго (sic.) саєлана, contrary to Qp18 and other two copies, which include кєлия; not комора. Therefore, it can be assumed that a rewriting, or a modification, in transmission took place somewhere between the original pattern and the TSL122.

In the course of transmission of the Dream, at the same time, a particular set of remarks on Lebanon was extracted from the exegesis of Psalms to form a textual unit and inserted after the Dream. This happened probably when O, or its antigraph, was composed, and the pattern thus made was reflected to V113 and, later, RGD. That $\mathrm{R}$ was on the transmission line of $\mathrm{Q}-\mathrm{IA}-\mathrm{R}$ is indicated by the fact that the remarks on "Lebanon" appearing after the Dream in RGD are followed by the last phrase of the SolChalT, which is mostly identical to the equivalent part of the SolChalT in Qp18: 


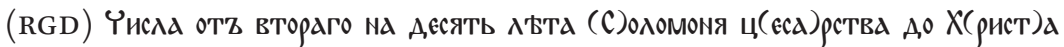
$\lambda$ '́TZ 900 и 956

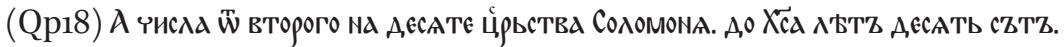
и. $\Theta . \wedge$ 'TZ $^{57}$

In the later transmission, however, the connectedness of the Dream and SolChalT was lost, and the Dream was mostly included in exegetical and didactic writings.

As was observed in 3.2, a phrase in the narrative of Jehoash's dream depicting

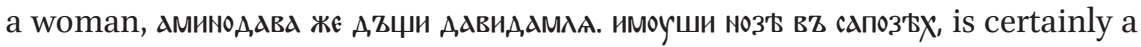
modification of Song 7:2., and we read an equivalent expression in the Old Slavonic translation of Song.

However, the name appearing in the corresponding part in the Greek version, such as in LXX, is not "Aminadav" or "Aminodav" but "Nadab": $\delta\llcorner\alpha \beta \eta \mu \alpha \tau \dot{\alpha}$

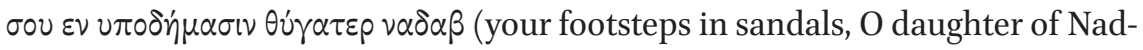
ab). In fact, $\nu \alpha \delta \alpha \beta$ is a literary copy, or a transliteration from Hebrew נדיב (nadib), ${ }^{58}$ and, therefore, in Latin translation (the Vulgate) this part reads fida principis.

Here, questions arise: where did the expression "дъчи Амїнадамовд” in the old Slavonic translation of Song come from? Also, how could the phrase "дминодАва же дъчи А,АвидамлА” in the Dream be so close to the Slavonic version of Song? Possible answers may be either that (1) the Slavonic translation of Song was based on a Greek version in which $\alpha \mu \nu \nu \alpha \delta \alpha \beta$ appeared instead of $\nu \alpha \delta \alpha \beta, 59$ while the Dream was also composed by relying on a Greek version in which the word $\alpha \mu \imath \nu \alpha \delta \alpha \beta$ appeared, and, as a result, it turned out that the two expressions in question in the Slavonic versions of Song and the Dream conform, or (2) аминадава in the Dream was directly composed on the basis of the Slavonic translation of the Song, in which the original $\nu \alpha \delta \alpha \beta$ or possibly $\alpha \mu \tau \alpha \delta \alpha \beta$ in Greek was translated into аминад,дв.

56 Каштанов, “Русь и Фессалоника," p. 96.

57 Wątróbska, The izbornik, p. 4.

$5^{8}$ A. Pietersma, B.G. Wright, A new English translation of the Septuagint: And the other Greek translations traditionally included under that title, New York, 2007, p. 659.

59 Septuaginta, ed. Rahlfs, p. 268; Алексеев, Песнь песней, p. 212. 
Although there is no proof to support either option, we may opt to consider that the second option was what actually happened on account of its simplicity and higher probability than the first option. If so, an assumption would arise that the whole story of the Dream was not a translation but a creation by a Slav; most likely by one who was working in the South Slavic writing tradition. Judging from the varied utilization of biblical books, such as the Song, Ecclesiastes, and Kings, and of exegetical texts related to them, the composer of the Dream was most likely a scribe, or a compiler, of such religious and didactical books and pieces. Inspired by these texts, he composed this small piece taking advantage of his own experience and knowledge.

The Dream has been regarded as apocryphal, but, as our observation revealed, this piece is not in fact an apocryphon but a composition created by way of combining an apocryphal narrative and the exegetical style that was quite popular in Byzantine-Orthodox literature. The connectedness of the Dream with the SolChalT in their early transmission may be explained by the similarity of their textual characteristics. Because of this structural resemblance, these two stories were probably perceived as being very close by scribes and compilers of medieval Slavonic texts.

Needless to say, there might have been a Greek text that could serve as a source of the Dream, as was the case with the Story of Solomon's Chalice. Brought into the Slavic world, the original text could have been transformed so as to become a Slavonic version of the Dream.

In any case, this short piece serves us with good material to observe the process of the early development and perception of the biblical and exegetical writings in Slavia Orthodoxa.

\section{Abbreviations}

RGADA Russian State archive of old documents [Российский государственный архив древних актов]

RNL Russian National Library (Petersburg)

RSL Russian State Library (Moscow) 